Thorax, 1977, 32, 287-295

\title{
Lung mast cells in rats exposed to acute hypoxia, and chronic hypoxia with recovery
}

\author{
A. WILliaMS, D. HEATH, J. M. KAY, AND P. SMITH \\ From the Department of Pathology, University of Liverpool
}

Williams, A., Heath, D., Kay, J. M., and Smith, P. (1977). Thorax, 32, 287-295. Lung mast cells in rats exposed to acute hypoxia, and chronic hypoxia with recovery. Exposure to acute hypoxia (barometric pressure $263 \mathrm{mmHg}$ ) for 8 hours did not lead to increased numbers of mast cells in the lungs of rats. In contrast, in adult rats kept for 35 days at a barometric pressure of $380 \mathrm{mmHg}$ there was a proliferation of mast cells around the pulmonary blood vessels and in the alveolar septa. This hyperplasia of lung mast cells in response to chronic hypoxia was reversible on removal of the hypoxic stimulus. There was a correlation between the logarithm of the perivascular lung mast cell density (defined in the paper) and the logarithm of the right ventricular weight. There was no increase in the mast cells in the carotid bodies of the hypoxic rats. Young male, old male, young female, and old female rats which had been subjected for 39 days to a barometric pressure of $380 \mathrm{mmHg}$ showed a proliferation of mast cells around the pulmonary blood vessels and in the alveolar walls. This response was greatest in the adult animals and independent of their sex. In the age and sex experiment there was a correlation between the perivascular lung mast cell density and the medial thickness of the muscular pulmonary arteries. Since mast cell hyperplasia has been reported as preceding right ventricular hypertrophy, it is conceivable that mast cell proliferation in the lung may be a defence mechanism to limit the severity of hypoxic pulmonary hypertension rather than to mediate it.

During the past few years we have carried out a series of experiments on the effects of chronic alveolar hypoxia on the lungs and heart. Among other things we have investigated the reversibility of the morbid anatomical changes induced in the heart and small pulmonary arteries (Abraham $e t$ al., 1971), and pulmonary trunk and carotid bodies (Heath et al., 1973), and the effects of age and sex on the response of the right ventricle and pulmonary vasculature to hypoxia (Smith et al., 1974). Recently the rôle of the mast cells in the hypoxic lung has aroused interest, and it has been suggested that in rats and guinea-pigs the perivascular pulmonary mast cell may be an important structure in the mediation of the pulmonary vasoconstrictor response to acute alveolar hypoxia (Haas and Bergofsky, 1972). Exposure of rats to chronic hypoxia for three weeks has been reported as leading to a proliferation of mast cells around small pulmonary blood vessels and within the alveolar walls (Kay et al., 1974; Mungall and Barer, 1975; Mungall, 1976). The magnitude of the mast cell hyperplasia correlates with the degree of right ventricular hypertrophy, suggesting that in the rat pulmonary mast cells may be connected in some way with chronic hypoxic pulmonary hypertension.

To investigate this problem further, we have exposed rats to severe acute hypoxia to see if hyperplasia of mast cells occurs in their lungs. We have also carried out a retrospective study on lung tissue derived from two previous chronic experiments on rats to determine whether the hyperplasia of mast cells was reversible once the hypoxic stimulus had been removed (Heath et al., 1973), and whether the hyperplasia was affected by the age and sex of the experimental animals (Smith et al., 1974). We were able to use paraffin-embedded material from previous experiments since in the rat mast cell granules are insoluble in aqueous fixatives. We have investigated the relation between the number of mast cells on the one hand and the right ventricular weight and medial thickness of muscular pulmonary arteries on the other. Finally we 
counted the number of mast cells in the carotid body to see if they also proliferated under the influence of chronic hypoxia.

\section{Material and methods}

RATS EXPOSED TO ACUTE HYPOXIA

Ten adult female Wistar albino rats weighing from $210 \mathrm{~g}$ to $230 \mathrm{~g}$ were divided into five test animals and five controls. The test rats were subjected to a constant barometric pressure of $263 \mathrm{mmHg}$ in a decompression chamber simulating an altitude of $7944 \mathrm{~m}$ above sea level for a period of 8 hours. The control animals were kept at sea level atmospheric pressure. On removal from the hypobaric chamber the test rats were anaesthetised with sodium pentobarbitone given intraperitoneally at $50 \mathrm{mg} / \mathrm{kg}$ body weight. The trachea was cannulated and $2 \%$ glutaraldehyde solution was infused into the lungs at a constant pressure of $20 \mathrm{~cm} \mathrm{H}_{2} \mathrm{O}$. The thoracic cage was gently massaged to allow escape of gases from the lungs. This procedure ensured that the lungs of different animals were fixed with a similar degree of expansion. Following fixation for $1 \frac{1}{2}$ hours at this constant pressure in situ the trachea was ligated and the thoracic viscera were removed in one block. The heart and lungs were dissected free and the lungs were placed in $2 \%$ glutaraldehyde for fixation. The lungs of the control rats were treated identically. After fixation one block of tissue from each of the five lung lobes of each rat was embedded in paraffin wax. One section from each block was cut, $5 \mu \mathrm{m}$ thick, and stained with $0.2 \%$ metachromatic blue in $5 \%$ aluminium sulphate. The number and distribution of the pulmonary mast cells in the control and hypoxic rats were obtained according to the method described below.

\section{RATS EXPOSED TO CHRONIC HYPOXIA}

Tissues from the recovery study of Heath et al. (1973)

Three groups of 10 adult male Wistar albino rats weighing from $315 \mathrm{~g}$ to $425 \mathrm{~g}$ were used. A 'hypoxic' group was kept for $\mathbf{3 5}$ days in a hypobaric chamber and exposed to a barometric pressure of $380 \mathrm{mmHg}$, simulating an elevation of $5500 \mathrm{~m}$, and then killed. A 'recovery' group was exposed to the same barometric pressure for 35 days and then allowed to recover in room air at sea level for a further five weeks. A control group was kept at sea level barometric pressure throughout the study. At necropsy the thoracic viscera were removed and the lungs were distended via tracheal cannulation with $4 \%$ formaldehyde until the pleural surfaces were smooth. The whole of the thoracic $\stackrel{\vec{F}}{\vec{F}}$ viscera were placed in the same solution for $\frac{}{2}$ fixation. A block of tissue was taken from each lung and embedded in paraffin wax. The carotid $\frac{\infty}{\sigma}$ bodies from each rat were fixed and embedded $\propto$ similarly. For the present study a section $5 \mu \mathrm{m}$ ڤ thick was cut from the right and left lung blocks $\vec{\circ}$ and stained with $0.2 \%$ metachromatic blue in $5 \%$ aluminium sulphate. A section, $5 \mu \mathrm{m}$ in thick- $\vec{\omega}$ ness, was also taken from near the centre of each $\stackrel{\rho}{\vec{*}}$ block of carotid body tissue and stained identically. $\times$ Counts of the pulmonary mast cells and carotid body mast cells of these sections were made as $\omega$ described below.

Tissues from the age and sex study of Smith et al. (1974)

Four groups of four Wistar albino rats (young male, young female, adult male, and adult female) ${ }_{\vec{\Phi}}^{\Phi}$ whose mean body weights were respectively $102 \mathrm{~g},-$ $100 \mathrm{~g}, 276 \mathrm{~g}$, and $238 \mathrm{~g}$, were kept in a decompres- sion chamber for 39 days at a barometric pressure? of $380 \mathrm{mmHg}$, equivalent to an elevation of $5500 \mathrm{~m}$. Four similar control groups were kept at sea level barometric pressure. At necropsy theô lungs were distended with $4 \%$ formaldehyde as $\stackrel{\mathbb{Q}}{\varrho}$ described previously. A block of tissue from each $\overrightarrow{\vec{\sigma}}$ of the five lung lobes of each rat was taken from 3 each animal and embedded in paraffin wax. For the present study a section $5 \mu \mathrm{m}$ thick was cuto from each of the five blocks of lung tissue from each animal and stained with $0.2 \%$ metachromatico blue in $5 \%$ aluminium sulphate. Mast cell counts were performed on each of these sections from each animal as described below.

PULMONARY MAST CELL COUNTS

In the lung, mast cells are found in the pleura, the peribronchial connective tissue, the perivascular connective tissue (Fig. 1), and the alveolar septa. Pleural mast cells were regarded for the purposes o of this study as extrapulmonary and were notn counted. The mast cell counts were performed using a microscope fitted with a square graticule ${ }^{\omega}$ and at a magnification of $\times 120$. The area of the section bounded by the graticule at this magnifica $\frac{0}{\bar{t}}$ tion was $0.392 \mathrm{~mm}^{2}$. By moving the microscopes stage vertically and horizontally in a systematic manner, mast cells within most of the lung substance bounded by the pleura were counted. Perivascular, peribronchial, and alveolar mast cells were counted separately in each field delineated by the graticule. Perivascular mast cells were defined as those in and immediately surrounding the adventitia of both pulmonary arteries and veins? 


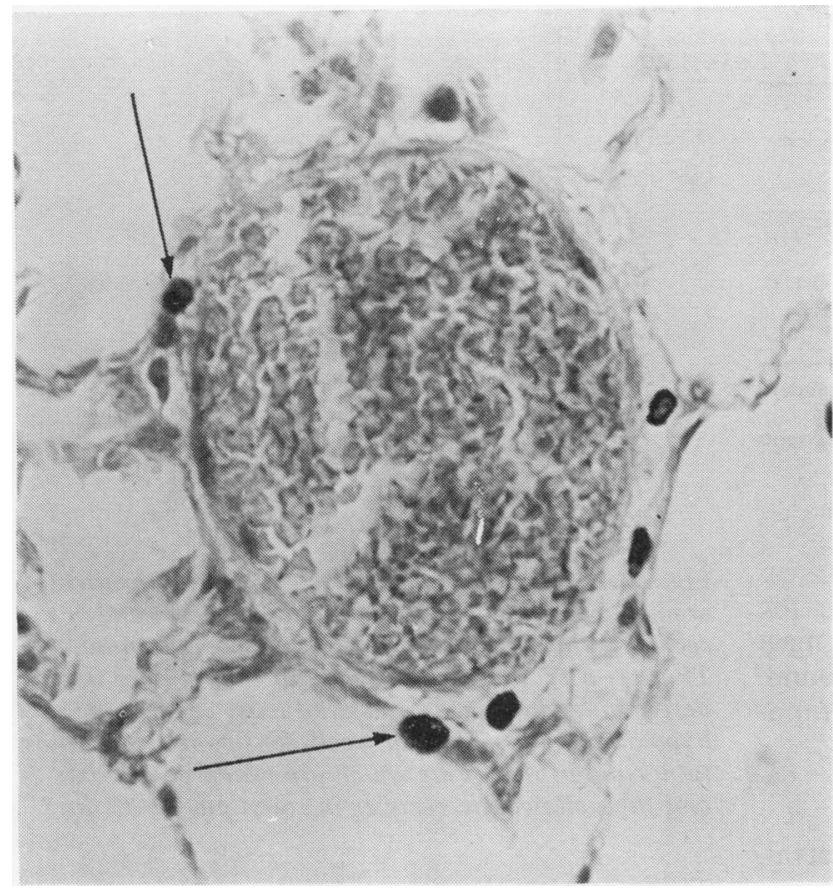

Fig. $1 A$ muscular pulmonary artery from a rat in the recovery study which had been kept in a hypobaric chamber at a barometric pressure of $380 \mathrm{mmHg}$ for 35 days. The adventitia of the vessel contains several darkly staining mast cells (arrowed). (Metachromatic blue $\times 600$ )

Mast cells in the perivascular space were included. Peribronchial mast cells were defined as those in and immediately surrounding the peribronchial connective tissue. Alveolar septal mast cells were those in the alveolar septa. The numbers of perivascular, peribronchial, and alveolar septal mast cells and the total number of mast cells were divided by the total number of graticule unit fields counted. These ratios of mast cells per unit area are henceforth referred to as 'lung mast cell densities'. The mean lung mast cell densities of each rat were obtained from the number of lung sections counted, and subsequently the average mean perivascular, peribronchial, alveolar septal and total mean lung mast cell densities were calculated for each experimental group.

\section{CAROTID BODY MAST COUNTS}

The total number of mast cells within both carotid body sections from each rat were counted at a magnification of $\times 120$. An estimate of the area of the carotid body cross-section was obtained by counting the number of unit graticule areas at a microscope magnification of $\times 480$ required to cover the surface area of the carotid bodies when the microscope stage was moved horizontally and vertically in a systematic manner. At the magnifcation of $\times .480$ the area of the section bounded by the graticule was $0.0259 \mathrm{~mm}^{2}$. The carotid body mast cell count was then divided by the estimate of carotid body area, and the ratio is henceforth called the 'carotid body mast cell density'. The carotid body mast cell density unit differs from the lung mast cell density as the areas used to calculate the ratios differ. The mean carotid body mast cell density in each rat was obtained and the average mean carotid body mast cell density and average mean carotid body mast cell count were calculated for each of the three experimental groups (hypoxic, recovery, and control).

\section{DATA ANALYSIS}

Differences between lung mast cell densities were compared using the Student's $t$ test. Where more than two means required comparison the analysis of variance technique was used. Correlations between the lung mast cell density on the one hand and the right ventricular weight and medial thickness of the muscular pulmonary arteries on the other were sought using linear regression analysis.

\section{Results}

RATS EXPOSED TO SEVERE ACUTE HYPOXIA

The perivascular, peribronchial, alveolar septal, and total lung mast cell densities of the hypoxic and control rats are shown in Table 1. There was no significant difference in their values between 
Table 1 Average* lung mast cell density in rats exposed for 8 hours to severe acute hypoxia

\begin{tabular}{lllll}
\hline $\begin{array}{l}\text { Experi- } \\
\text { mental } \\
\text { group }\end{array}$ & \multicolumn{3}{l}{ Average mast cell density } & \\
\cline { 2 - 5 } & Perivascular & $\begin{array}{l}\text { Peribron- } \\
\text { chial }\end{array}$ & $\begin{array}{l}\text { Alveolar } \\
\text { septal }\end{array}$ & Total \\
\hline $\begin{array}{l}\text { Test }(\mathrm{n}=5) \\
\begin{array}{l}\text { Control } \\
(\mathrm{n}=5)\end{array}\end{array}$ & $0.70( \pm 0.27)$ & $0.22( \pm 0.08)$ & $0.07( \pm 0.03)$ & $0.99( \pm 0.34)$ \\
$\begin{array}{l}\text { Statistical } \\
\text { comparison } \dagger\end{array}$ & $t=1.73$ & $t=1.91$ & $t=0.81$ & $t=1.85$ \\
\hline
\end{tabular}

The figures in parentheses in Tables 1 to 4 represent \pm one standard deviation.

*For each rat five lung sections were counted, the mean of the five counts was obtained, and the group average of these means is quoted.

$\dagger$ No significant difference between test and control values.

Graticule area $=0.392 \mathrm{~mm}^{2}$. To convert number of mast cells per graticule area to number per $\mathrm{mm}^{2}$, multiply by $2 \cdot 55$.

hypoxic and control rats. No differences in the histological appearance of the pulmonary mast cell from hypoxic and control rats were found. However, cell counts of granulated and ungranulated mast cells were not carried out.

\section{RATS EXPOSED TO CHRONIC HYPOXIA}

Tissues from the recovery study of Heath et al. (1973)

The lungs of one of the control rats showed histological evidence of severe chronic inflammation and were, therefore, excluded from the study. The lung mast cell densities of the hypoxic, recovery, and control groups of rats are shown in Table 2. In the hypoxic rats the perivascular, alveolar septal, and total lung mast cell densities were significantly greater than the corresponding values in the control and recovery groups (Fig. 2). There was no significant difference between these values in the control and recovery groups. No significant difference was found between the peribronchial mast cell density in the three experimental groups.

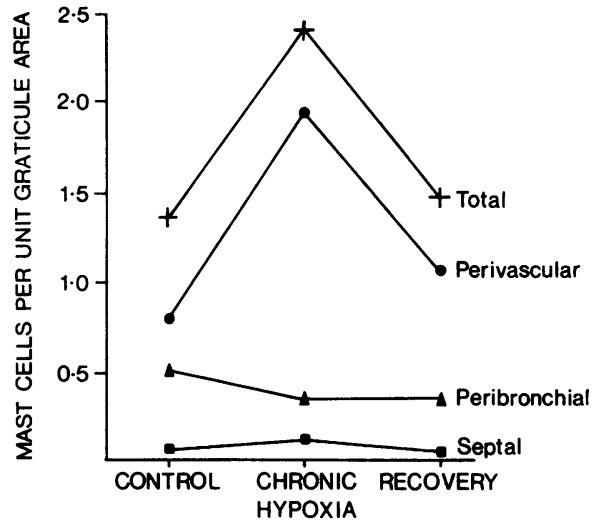

Fig. 2 Number of lung mast cells per unit graticule area (mast cell density) in control, hypoxic, and recovery rats taken from the recovery experiment. There is a pronounced increase in the number of perivascular mast cells and total mast cells in the hypoxic animals. The mast cell density returns almost to normal in those rats which are rendered hypoxic and then allowed to recover in room air for 35 days.

There was no significant difference in the carotid body mast cell density of the control, recovery, and hypoxic groups (Table 3). However, the total carotid body mast cell count was greater in the hypoxic rats than in the control and recovery rats.

The hypoxic animals showed right ventricular hypertrophy, medial hypertrophy of the pulmonary trunk, and enlargement of the carotid body (Heath et al., 1973). In the recovery group these changes had regressed. The group mean value of the medial thickness of the 'muscular pulmonary arteries' in the hypoxic animals $(4 \cdot 3 \%)$ showed a statistically significant increase compared to the control $(3.4 \%)$ and recovery $(2.5 \%)$ group mean

Table 2 A verage lung mast cell density in rats exposed chronically to simulated high altitude and recovering from such exposure

\begin{tabular}{|c|c|c|c|c|}
\hline \multirow{2}{*}{$\begin{array}{l}\text { Experimental } \\
\text { group }\end{array}$} & \multicolumn{4}{|c|}{ Average mast cell density } \\
\hline & Perivascular* & Peribronchial & Alveolar septal* & Total* \\
\hline $\begin{array}{l}\text { Control }(n=9) \\
\text { Simulated high altitude } \\
(n=10) \\
\text { Recovery }(n=10)\end{array}$ & $\begin{array}{l}0.79( \pm 0.34) \\
1 \cdot 93( \pm 0 \cdot 55)^{1,2} \\
1 \cdot 05( \pm 0.40)\end{array}$ & $\begin{array}{l}0.50( \pm 0.27) \\
0.34( \pm 0.07) \\
0.35( \pm 0.15)\end{array}$ & $\begin{array}{l}0.06( \pm 0.03) \\
0.12( \pm 0.05)^{3,4} \\
0.05( \pm 0.02)\end{array}$ & $\begin{array}{l}1 \cdot 35( \pm 0 \cdot 54) \\
2 \cdot 40( \pm 0 \cdot 61)^{5,6} \\
1 \cdot 47( \pm 0 \cdot 49)\end{array}$ \\
\hline
\end{tabular}

* Group means differ significantly all $\mathrm{P}<0.001$ (analysis of variance).

${ }^{1}$ Significantly different from control value $t=5.40, \mathrm{P}<0.001$

Significantly different from recovery value $t=4 \cdot 11, \mathrm{P}<0.001$

${ }^{3}$ Significantly different from control value $t=3 \cdot 56, \mathrm{P}<0.005$

- Significantly different from recovery value $t=5.60, \mathrm{P}<0.001$

significantly different from control value $t=3.95, \mathrm{P}<0.005$

- Significantly different from recovery value $t=3 \cdot 80, \mathrm{P}<0.005$

For each rat two lung sections were counted, the mean of the two counts was obtained, the group average of these means is quoted.

Graticule area $=0.392 \mathrm{~mm}^{2}$. To convert number of mast cells per graticule area to number per mm², multiply by 2.55 . 
Table 3 Total number of mast cells in carotid body and carotid body mast cell density in rats exposed chronically to simulated high altitude and recovering from such exposure

\begin{tabular}{|c|c|c|}
\hline $\begin{array}{l}\text { Experimental } \\
\text { group }\end{array}$ & $\begin{array}{l}\text { Total number of } \\
\text { mast cells* }\end{array}$ & Mast cell density $\dagger$ \\
\hline $\begin{array}{l}\text { Control }(n=10) \\
\text { Simulated high } \\
\text { altitude }(n=10) \\
\text { Recovery }(n=10)\end{array}$ & $\begin{array}{l}13 \cdot 1( \pm 2 \cdot 5) \\
23 \cdot 7( \pm 10 \cdot 6) \\
19 \cdot 8( \pm 6 \cdot 4)\end{array}$ & $\begin{array}{l}0.169( \pm 0.063) \\
0.151( \pm 0.033) \\
0.191( \pm 0.058)\end{array}$ \\
\hline
\end{tabular}

* These mean values differ significantly ( $P<0.05$ (analysis of variance)). tThese mean values do not differ significantly (analysis of variance).

For each rat one section from the right and left carotid bodies was counted, the mean value was obtained, and the group average of these means is quoted.

Graticule area $=0.0259 \mathrm{~mm}^{2}$. To convert mast cell density to numbers of mast cells per $\mathrm{mm}^{2}$ multiply by $38 \cdot 61$.

values. However, obvious medial hypertrophy of these arteries was not apparent on examination of the sections. There was a significant correlation between the logarithm of the perivascular lung mast cell density and the logarithm of the right ventricular weight $(\mathrm{r}=0.6179 ; \mathrm{p}<0.001)$ in the control, hypoxic, and recovery groups of rats.

Tissues from the age and sex study of Smith et al. (1974)

The perivascular, peribronchial, alveolar septal, and total lung mast cell densities are shown in Table 4.

A three-factor analysis of variance (testing the experimental factors age, sex, and exposure to simulated high altitude and their interactions) showed:

1 a significantly greater perivascular $(P<0.01)$, alveolar septal $(\mathrm{P}<0.05)$, and total $(\mathrm{P}<0.01)$ lung mast cell density in hypoxic compared to control rats; and

2 a significantly greater perivascular $(\mathrm{P}<0.01)$, alveolar septal $(P<0.05)$, and total $(P<0.01)$ lung mast cell density in adult hypoxic compared to young hypoxic rats (both male and female).

Peribronchial mast cell densities were not significantly different in the hypoxic compared to the control rats.

Each of the four hypoxic groups showed right ventricular hypertrophy and medial hypertrophy of the pulmonary trunks (Smith et al., 1974). Medial hypertrophy of the small pulmonary arteries was found only in the adult female group. Again the group mean values of the medial thickness of the 'muscular pulmonary arteries' of each group of test animals showed a statistically significant increase compared to the control groups. Only four hypoxic rats had values of medial thick-
Table 4 Average lung mast cell density in rats of different ages and sex exposed chronically to simulated high altitude

\begin{tabular}{|c|c|c|c|c|}
\hline \multirow{2}{*}{$\begin{array}{l}\text { Experi- } \\
\text { mental } \\
\text { group }\end{array}$} & \multicolumn{4}{|c|}{ Average mast cell density } \\
\hline & Perivascular & $\begin{array}{l}\text { Peribron- } \\
\text { chial }\end{array}$ & $\begin{array}{l}\text { Alveolar } \\
\text { septal }\end{array}$ & Total \\
\hline \multirow{2}{*}{$\begin{array}{l}\text { Young } \\
\text { females } \\
\text { Controls } \\
(n=4) \\
\text { Hypoxic } \\
(n=4)\end{array}$} & $0.69( \pm 0.32)$ & $0.40( \pm 0.01)$ & $0.04( \pm 0.02)$ & $1 \cdot 13( \pm 0 \cdot 36)$ \\
\hline & $1.62( \pm 0.56)$ & $0.21( \pm 0.12)$ & $0.06( \pm 0.04)$ & $1.90( \pm 0.72)$ \\
\hline \multirow{2}{*}{$\begin{array}{l}\text { Adult females } \\
\begin{array}{l}\text { Controls } \\
(n=4)\end{array} \\
\text { Hypoxic } \\
(n=4)\end{array}$} & $0 \cdot 37( \pm 0 \cdot 15)$ & $0 \cdot 16( \pm 0 \cdot 12)$ & $0.04( \pm 0.03)$ & $0.55( \pm 0.23)$ \\
\hline & $4 \cdot 06( \pm 1 \cdot 60)$ & $0.36( \pm 0.01)$ & $0.85( \pm 0.84)$ & $5 \cdot 28( \pm 2 \cdot 33)$ \\
\hline \multirow{2}{*}{$\begin{array}{c}\text { Young males } \\
\text { Controls } \\
(n=4) \\
\text { Hypoxic } \\
(n=4)\end{array}$} & $0.87( \pm 0.46)$ & $0.25( \pm 0.15)$ & $0.06( \pm 0.07)$ & $1 \cdot 19( \pm 0 \cdot 61)$ \\
\hline & $2 \cdot 01( \pm 0 \cdot 81)$ & $0.38( \pm 0.13)$ & $0.10( \pm 0.05)$ & $2 \cdot 51( \pm 0.91)$ \\
\hline \multirow{2}{*}{$\begin{array}{c}\text { Adult males } \\
\begin{array}{l}\text { Controls } \\
(\mathrm{n}=4)\end{array} \\
\text { Hypoxic } \\
(\mathrm{n}=4)\end{array}$} & $0.58( \pm 0.23)$ & $0.16( \pm 0.08)$ & $0.04( \pm 0.03)$ & $0.79( \pm 0.31)$ \\
\hline & $3 \cdot 67( \pm 2 \cdot 18)$ & $0.48( \pm 0.35)$ & $0.66( \pm 0.68)$ & $4 \cdot 82( \pm 3 \cdot 17)$ \\
\hline
\end{tabular}

For each rat five lung sections were counted, the mean of the five counts was obtained, and the group average of these means is quoted.

Graticule area $=0.392 \mathrm{~mm}^{2}$. To convert number of mast cells per graticule area to number per $\mathrm{mm}^{2}$ multiply by $2 \cdot 55$.

ness per cent above 7.0. In all the test and control rats there was a significant correlation between the logarithm of the right ventricular weight on the one hand and the logarithm of the total lung mast cell density $(r=0.7043 ; P<0.001)$ and the logarithm of the perivascular mast cell density $(r=0.7425 ; P<0.001)$ on the other. In the hypoxic and control animals there was a correlation between the medial thickness of muscular pulmonary arteries and perivascular mast cell density $(\mathrm{r}=0.5368 ; \mathrm{P}<0.01)$.

\section{Discussion}

This study has confirmed the observations of Kay et al. (1974), Mungall and Barer, (1975) and Mungall (1976) that a hyperplasia of mast cells occurs around the pulmonary blood vessels and within the alveolar walls of rats exposed to chronic hypoxia, and that the intensity of the mast cell hyperplasia is related to the degree of right ventricular hypertrophy. However, these observations have been extended by the present investigation which has revealed that the hyperplasia of mast cells in the lung is reversible once the hypoxic stimulus has been removed. The extent of the proliferation appears to be independent of sex but 
it is more pronounced in adult animals. In the chronically hypoxic rats in the age and sex series the perivascular lung mast cell density correlates with the medial thickness of the muscular pulmonary arteries, suggesting that the thickest muscular arteries have the most mast cells in their adventitial coats. Acute hypoxia for eight hours does not induce a proliferation of mast cells in the lungs.

In this study we made no attempt to distinguish between periarterial and perivenous mast cells. In retrospect this was a mistake for it is likely that additional data would have been obtained, especially with respect to the rôle of the pulmonary mast cell in differential constriction of pulmonary arteries and veins in states of chronic hypoxia. We recommend that further histological studies in this field should attempt to make this distinction.

The lack of change in the number of mast cells in the carotid bodies in response to chronic hypoxia suggests that the mast cell hyperplasia seen in the lung is not a general phenomenon within the body tissues, which accords with previous observations (Kay and Grover, 1975). The increase in the total number of mast cells in the carotid bodies of the hypoxic rats merely reflects the increased size of the carotid bodies in these animals, since no difference is seen in the carotid body mast cell count per unit area.

The functional significance of the proliferation of mast cells in the lungs of rats exposed to chronic hypoxia is still not clear. Recently the view has gained ground that in some way they are concerned with the pulmonary vasoconstriction induced by hypoxia. The concept of such an intermediary agent is based on the premise that alveolar hypoxia is much more potent as a pulmonary vasoconstrictor than hypoxaemia, but even this basic premise has recently been challenged by Fishman (1976). If one accepts the idea, however, it is clear that the periarterial mast cell is in a most strategic position to act as an intermediary, being stimulated by the hypoxic air in the adjacent alveolar spaces and liberating some humoral agent from its electron-dense secretory granules (Fig. 3) to affect the media of the muscular pulmonary arteries. Certainly mast cells contain a number of vasoactive substances, including 5-hydroxytryptamine and histamine (Selye, 1965). All the evidence suggests that the former is not involved in the hypoxic response (Lloyd, 1964; Bergofsky, 1974; Harris and Heath, 1977). Hence the favoured chemical mediator is histamine. In the isolated perfused rat lung large doses of antihistamine and histamine-depleters diminish the pulmonary pres- sor response to hypoxia whereas a histaminase in- $\frac{\overrightarrow{\vec{S}}}{\rightarrow}$ hibitor potentiates it (Altura and Zweifach, 1965; Hauge and Melmon, 1968; Hauge and Staub, 1969; Susmano and Carleton, 1971). Furthermore, during hypoxia the concentration of histamine in the $\odot$ venous effluent from the lungs increases (Aviado के et al., 1966; Haas and Bergofsky, 1972). Such data $\vec{\circ}$ are consistent with histamine causing pulmonary vasoconstriction in rats. There is also evidence to show that the same occurs in the dog. Kay and Grover (1975) investigated the effect of disodium cromoglycate (DSCG) on acute hypoxic pulmonary hypertension in this species. DSCG has the un- $\omega$ usual property of inhibiting the release of histamine from mast cells which is the basis for its clinical use in the treatment of bronchial asthma and other allergic conditions (Cox, 1971). It was found that if suitably reactive dogs were premedicated with DSCG they failed to increase their pulmonary vascular resistance while spontaneously breathing a hypoxic gas mixture which diminished . their systemic arterial oxygen tension to less than $40 \mathrm{mmHg}$. However, Howard et al. (1975) have been unable to confirm these findings, and Mungall (1976) failed to prevent the development of right ventricular hypertrophy in chronically hypoxic rats given daily treatment with DSCG.

A great difficulty in accepting histamine as the mediator of hypoxic pulmonary vasoconstriction is that it has been reported to produce both pulmonary vasodilatation (Dawes and Mott, 1962; Shaw, 1971; Silove and Simcha, 1973) and pulmonary vasoconstriction (Shaw, 1971; Porcelli and Bergofsky, 1973; Bergofsky, 1974). These apparently contradictory results obtained by different investigators using different species may be clarified by the following two observations. First, Colebatch (1970), working with intact and adrenalectomised cats, obtained evidence that exogenous histamine $D$ only constricts pulmonary arteries and that pulmonary vasodilatation depends on epinephrine re- $N$ leased by histamine from the adrenal glands. This suggests that endogenous histamine released locally within the lungs would cause pulmonary vasoconstriction. Colebatch's work would explain why exogenous histamine constricts blood vessels in $\varrho$ isolated lungs but tends to dilate such blood vessels $\mathbb{\varnothing}$ in intact animals. Secondly, $\mathrm{H}_{1}$ and $\mathrm{H}_{2}$ receptors : have been demonstrated in isolated perfused guinea-pig lungs (Okpako, 1972; Turker, 1973) and in the intact cat (Barer et al., 1976) and dog (Tucker et al., 1975). The latter group of workers studied the magnitude and time course of the $\mathrm{H}_{1}$ ? receptor-induced vasoconstrictor and $\mathrm{H}_{2}$ receptor- 8 induced vasodilator responses to histamine. When 


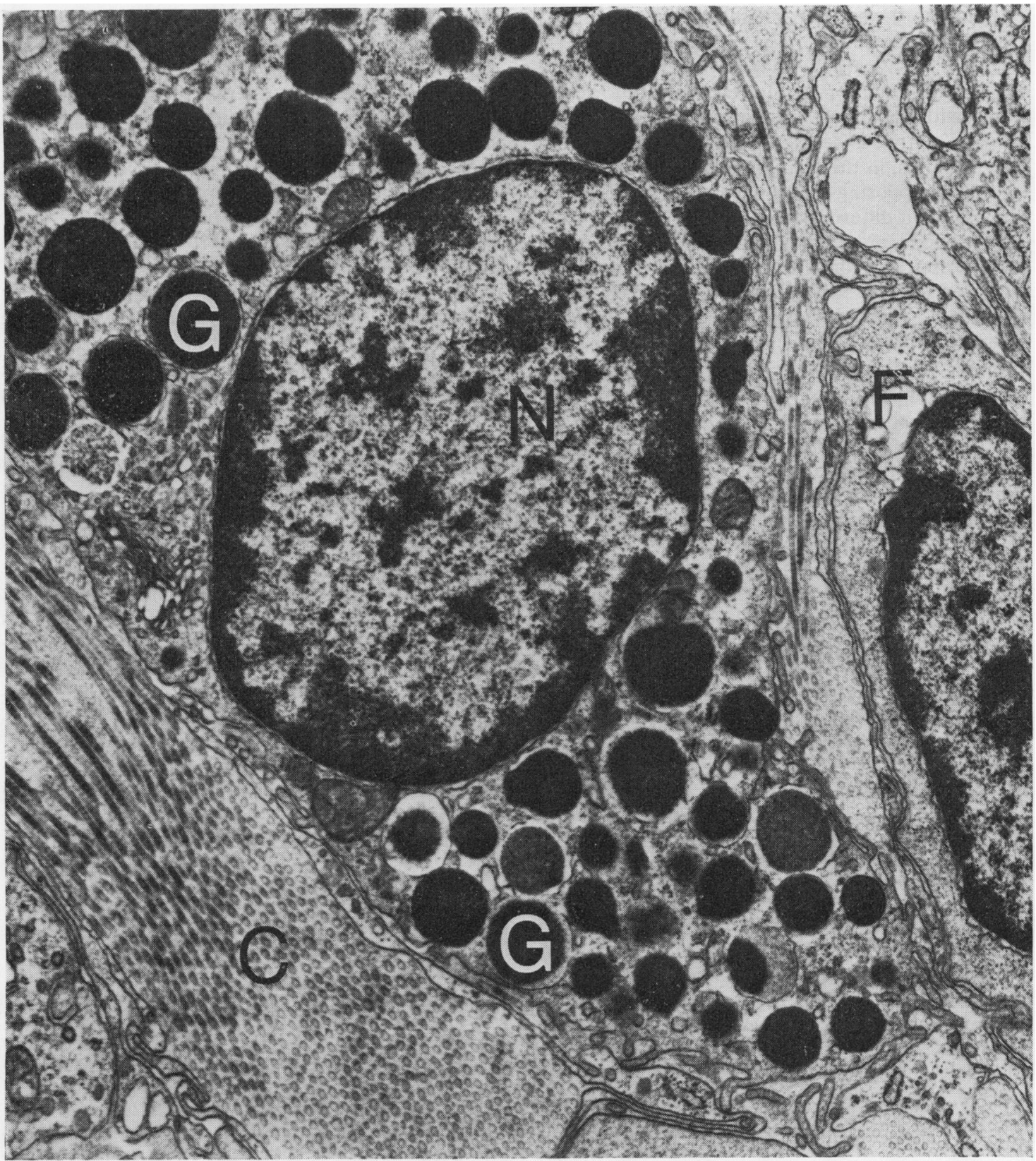

Fig. 3 A perivascular mast cell as seen under the electron microscope. It contains a large central nucleus $(N)$ and numerous electron-dense secretory granules $(G)$ which in favourable sections can be seen to be bounded by a single limiting membrane. It is these granules which are believed to contain vasoactive substances. The mast cell is surrounded by collagen fibrils $(C)$ and fibrocytes $(F)$ of the adventitia of the vessel. Electron micrograph $\times 18750$.

$H_{1}$ receptors were stimulated alone (by selectively blockading the $\mathrm{H}_{2}$ receptors) there was an abrupt pulmonary pressor response which was sustained for the duration of the histamine infusion. When both $\mathrm{H}_{1}$ and $\mathrm{H}_{2}$ receptors were stimulated simultaneously, the net result was a transient decrease 
in pulmonary vascular resistance followed by a progressive increase. The pulmonary vascular bed behaved as though there was an initial predominance of stimulation of $\mathrm{H}_{2}$ receptors followed by either withdrawal of stimulation of $\mathrm{H}_{2}$ receptors or by a relative increase in stimulation of $\mathrm{H}_{1}$ receptors. 'Thus, in the dog, histamine administration stimulates opposing pulmonary vascular responses which exhibit differential activation. The two histamine actions may affect different vessels or the same vessel according to its state of tone (Barer et al., 1976). In such circumstances it is hardly surprising that investigators using different methods and species have reported conflicting pulmonary vascular responses to histamine infusion.

Since clinicians are likely to be concerned mainly with the human pulmonary circulation it is worthy of note that in an extensive review of the literature on the pharmacology of the pulmonary circulation we found that in man the effects of exogenous histamine on the pulmonary circulation are vasodilator (Harris and Heath, 1977). Thus intravenous injections of histamine in a dose ranging from 0.1 to $0.45 \mu \mathrm{g} \mathrm{kg}^{-1} \mathrm{~min}^{-1}$ in five normal women caused pulmonary vascular resistance to fall on an average from 86 to $46 \mathrm{dyn} \mathrm{s}^{-1} \mathrm{~cm}^{-5}$ and in six normal men from 57 to 34 dyn s-1 $\mathrm{cm}^{-5}$ (Bjure et al., 1967). In eight subjects with mitral stenosis an intravenous dose of 0.1 to $0.3 \mu \mathrm{g} \mathrm{kg}^{-1}$ $\mathrm{min}^{-1}$ caused a fall of pulmonary vascular resistance of 221 to $114 \mathrm{dyn} \mathrm{s}^{-1} \mathrm{~cm}^{-5}$ (Lindell et al., 1964). Falls of comparable magnitude in pulmonary vascular resistance were reported in four subjects with constrictive pericarditis by Lindell et al. (1963) and in two normal subjects and in two patients with pulmonary disease by Bjure et al. (1966).

There is evidence that chronic interstitial pulmonary oedema may be associated with proliferation of mast cells in the alveolar walls. Thus the administration of hydrazine sulphate and monocrotaline to rats leads to the development of pulmonary oedema associated with mast cell proliferation (Kay et al., 1967). Mast cell proliferation has been observed in the lungs of patients suffering from mitral stenosis and chronic left ventricular failure and oedema of pulmonary alveolar walls (Heath et al., 1969). Sudden ascent to altitudes over $3000 \mathrm{~m}$ above sea level carries the risk of development of high altitude pulmonary oedema in susceptible human subjects (Heath and Williams, 1977). Accordingly, it is conceivable that in chronically hypoxic rats, simulating high altitude conditions, the lung mast cell hyperplasia might be due to chronic pulmonary oedema. How- ever, such rats show no histological evidence of $\frac{\overrightarrow{\bar{S}}}{\frac{1}{0}}$ pulmonary oedema (Kay et al., 1974). Furthermore, if chronic hypoxia did produce chronic $\frac{\bar{c}}{\bar{c}}$ interstitial pulmonary oedema, then eventually this $\overrightarrow{\widetilde{\sigma}}$ would surely lead to interstitial pulmonary fibrosis $\varrho$ such as occurs in mitral stenosis and chronic left $\mathrm{\omega}$ ventricular failure. We have not seen interstitial $\overrightarrow{0}$ pulmonary fibrosis in rats kept at a simulated alti- $\overrightarrow{-}$ tude of $4300 \mathrm{~m}$ for periods in excess of 400 days, $\stackrel{\omega}{\sigma}$ and interstitial pulmonary fibrosis is not a feature $\vec{F}$ of the lungs of high altitude dwellers.

The observations that the lung mast cell density increases with the right ventricular weight and $\omega$ medial thickness of the muscular pulmonary arteries in hypoxic rats, and that the mast cell $\circ$ hyperplasia regresses when the hypoxic stimulus is removed, suggest that the proliferation is associ- $\vec{C}$ ated in some way with the onset and regression of pulmonary hypertension. Mungall (1976) showed that in chronically hypoxic rats, the mast cells did $\vec{\ominus}$ not proliferate until after 21 days of exposure,. whereas right ventricular hypertrophy was ap-: parent after only 14 days. The fact that right ventricular hypertrophy apparently precedes lung mast cell hyperplasia makes it unlikely that it is

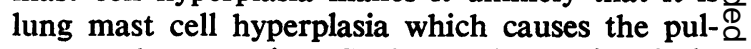
monary hypertension. Such an observation is in $\overrightarrow{\overrightarrow{0}}$ fact more consistent with the concept that pul- $\frac{0}{3}$ monary hypertension causes the mast cell hyperplasia. It is even conceivable that this hyperplasia? of mast cells in the lungs represents a defence mechanism which limits the severity of hypoxic응 pulmonary constriction and hypertension rather $\stackrel{\oplus}{\times}$ than mediates it, as has been suggested in the past.

This study was supported by a research grant $\stackrel{\delta}{\nexists}$ from the World Health Organization.

\section{References}

Abraham, A. S., Kay, J. M., Cole, R. B., and Pinock, N A. C. (1971). Haemodynamic and pathological study" of the effect of chronic hypoxia and subsequent re- ${ }^{\circ}$ covery of the heart and pulmonary vasculature of $\mathrm{N}_{\mathrm{W}}$

the rat. Cardiovascular Research, 5, 95-102.
Altura, B. M. and Zweifach, B. W. (1965). Pharmaco-o logic properties of antihistamines in relation to vascular reactivity. American Journal of Physiology, 209, 550-556.

Aviado, D. M., Samanék, M., and Folle, L. E. (1966). Cardiopulmonary effects of tobacco and related sub- $\mathrm{\Phi}$ stances. Archives of Environmental Health, 12, 705-724.

Barer, G. R., Emery, C. J., Mohammed, F. H., Mun-O gall, I. P. F., and Thompson, B. (1976). $\mathrm{H}_{1}$ and $\mathrm{H}_{2}$ histamine receptors in the pulmonary circulation Journal of Physiology, 259, 41 P. 
Bergofsky, E. H. (1974). Mechanisms underlying vasomotor regulation of regional pulmonary blood flow in normal and disease states. American Journal of Medicine, 57, 378-394.

Bjure, J., Helander, E., Lindell, S. E., Söderholm, B., and Westling, H. (1967). Effect of acetylcholine and histamine on the pulmonary circulation in normal men and women. Scandinavian Journal of Respiratory Diseases, 48, 214-226.

Bjure, J., Söderholm, B., and Widimsky, J. (1966). The effect of histamine infusion on pulmonary haemodynamics and diffusing capacity. Scandinavian Journal of Respiratory Disease, 47, 53-63.

Colebatch, H. J. H. (1970). Adrenergic mechanisms in the effects of histamine in the pulmonary circulation of the cat. Circulation Research, 26, 379-396.

Cox, J. S. G. (1971). Disodium cromoglycate. British Journal of Diseases of the Chest, 65, 189-204.

Dawes, G. S. and Mott, J. C. (1962). The vascular tone of the foetal lung. Journal of Physiology, 164, 465477.

Fishman, A. P. (1976). Hypoxia on the pulmonary circulation. How and where it acts. Circulation Research, 38, 221-231.

Haas, F. and Bergofsky, E. H. (1972). Role of the mast cell in the pulmonary pressor response to hypoxia. Journal of Clinical Investigation, 51, 31543162.

Harris, P. and Heath, D. (1977). The Human Pulmonary Circulation, 2nd edition. Churchill Livingstone, Edinburgh and London.

Hauge, A. and Melmon, K. L. (1968). Role of histamine in hypoxic pulmonary hypertension in the rat. II. Depletion of histamine, serotonin, and catecholamines. Circulation Research, 22, 385-392.

Hauge, A. and Staub, N. C. (1969). Prevention of hypoxic-vasoconstriction in cat lung by histaminereleasing agent 48/80. Journal of Applied Physiology, 26, 693-699.

Heath, D., Edwards, C., Winson, M., and Smith, P. (1973). Effects on the right ventricle pulmonary vasculature and carotid bodies of the rat of exposure to, and recovery from, simulated high altitude. Thorax, 28, 24-28.

Heath, D., Trueman, T., and Sukonthamarn, P. (1969). Pulmonary mast cells in mitral stenosis. Cardiovascular Research, 3, 467-471.

Heath, D. and Williams, D. R. (1977). Man at High Altitude. Churchill Livingstone, Edinburgh and London.

Howard, P., Barer, G. R., Thompson, B., Warren, P. M., Abbott, C. J., and Mungall, I. P. F. (1975). Factors causing and reversing vasoconstriction in unventilated lung. Respiration Physiology, 24, 325345.

Kay, J. M., Gillund, T. D., and Heath, D. (1967). Mast cells in the lungs of rats fed on Crotalaria spectabilis seeds. American Journal of Pathology, 51, 1031-1043.

Kay, J. M. and Grover, R. F. (1975). Lung mast cells and hypoxic pulmonary hypertension. In: Progress in Respiration Research, Vol. 9, Pulmonary Hypertension, pp. 157-164. Karger, Basle.

Kay, J. M., Waymire, J. C., and Grover, R. F. (1974). Lung mast cell hyperplasia and pulmonary histamine-forming capacity in hypoxic rats. American Journal of Physiology, 226, 178-184.

Lindell, S. E., Söderholm, B., and Westling, H. (1964). Haemodynamic effects of histamine in mitral stenosis. British Heart Journal, 26, 180-186.

Lindell, S. E., Svanborg, A., Söderholm, B., and Westling, H. (1963). Haemodynamic changes in chronic constrictive pericarditis during exercise and histamine infusion. British Heart Journal, 25, 35-41.

Lloyd, T. C., Jr. (1964). Effect of alveolar hypoxia on pulmonary vascular resistance. Journal of Applied Physiology, 19, 1086-1094.

Mungall, I. P. F. (1976). Hypoxia and lung mast cells: influence of disodium cromoglycate. Thorax, 31, 94-100.

Mungall, I. P. F. and Barer, G. R. (1975). Lung vessels and mast cells in chronically hypoxic rats. In: Progress in Respiration Research, Vol. 9, Pulmonary Hypertension, pp. 144-150. Karger, Basle.

Okpako, D. T. (1972). A dual action of histamine on guinea-pig lung vessels. British Journal of Pharmacology, 45, 311-321.

Porcelli, R. J. and Bergofsky, E. H. (1973). Adrenergic receptors in pulmonary vasoconstrictor responses to gaseous and humoral agents. Journal of Applied Physiology, 34, 483-488.

Selye, H. (1965). The Mast Cells. Butterworths, London.

Shaw, J. W. (1971). Pulmonary vasodilator and vasoconstrictor actions of histamine. Journal of Physiology, 215, 34P-35P.

Silove, E. D. and Simcha, A. J. (1973). Histamineinduced pulmonary vasodilation in the calf: relationship to hypoxia. Journal of Applied Physiology, 35, 830-836.

Smith, P., Moosavi, H., Winson, M., and Heath, D. (1974). The influence of age and sex on the response of the right ventricle pulmonary vasculature and carotid bodies to hypoxia in rats. Journal of Pathology, 112, 11-18.

Susmano, A. and Carleton, R. A. (1971). Prevention of hypoxic pulmonary hypertension by chlorpheniramine. Journal of Applied Physiology, 31, 531-535.

Tucker, A., Weir, E. K., Reeves, J. T., and Grover, R. F. (1975). Histamine $\mathbf{H}_{1}$ - and $\mathbf{H}_{2}$-receptors in pulmonary and systemic vasculature of the dog. American Journal of Physiology, 229, 1008-1013.

Turker, R. K. (1973). Presence of histamine $\mathbf{H}_{2}$-receptors in the guinea-pig pulmonary vascular bed. Pharmacology, 9, 306-311.

Requests for reprints to: Professor D. Heath, Department of Pathology, The University of Liverpool, New Medical School, Asthon Street, PO Box 147, Liverpool L69 3BX. 